\title{
Requirement of Mammalian Target of Rapamycin Complex 1 Downstream Effectors in Cued Fear Memory Reconsolidation and Its Persistence
}

\author{
Thu N. Huynh, Emanuela Santini, and Eric Klann \\ Center for Neural Science, New York University, New York, New York 10003
}

\begin{abstract}
Memory retrieval, often termed reconsolidation, can render previously consolidated memories susceptible to manipulation that can lead to alterations in memory strength. Although it is known that reconsolidation requires mammalian target of rapamycin complex 1 (mTORC1)-dependent translation, the specific contributions of its downstream effectors in reconsolidation are unclear. Using auditory fear conditioning in mice, we investigated the role of eukaryotic translation initiation factor 4E (eIF4E)- eIF4G interactions and p70 S6 kinase polypeptide 1 (S6K1) in reconsolidation. We found that neither 4EGI-1 (2-[(4-(3,4-dichlorophenyl)-thiazol-2-ylhydrazono)-3-(2nitrophenyl)]propionic acid), an inhibitor of eFI4E-eIF4G interactions, nor PF-4708671 [2-((4-(5-ethylpyrimidin-4-yl)piperazin-1yl)methyl)-5-(trifluoromethyl)-1H-benzo[d]imidazole], an inhibitor of S6K1, alone blocked the reconsolidation of auditory fear memory. In contrast, using these drugs in concert to simultaneously block eIF4E-eIF4G interactions and S6K1 immediately after memory reactivation significantly attenuated fear memory reconsolidation. Moreover, the combination of 4EGI-1 and PF-4708671 further destabilized fear memory $10 \mathrm{~d}$ after memory reactivation, which was consistent with experiments using rapamycin, an mTORC1 inhibitor. Furthermore, inhibition of $\mathrm{S} 6 \mathrm{~K} 1$ immediately after retrieval resulted in memory destabilization $10 \mathrm{~d}$ after reactivation, whereas inhibition of eIF4E- eIF4G interactions did not. These results indicate that the reconsolidation of fear memory requires concomitant association of eIF4E to eIF4G as well as $\mathrm{S} 6 \mathrm{~K} 1$ activity and that the persistence of memory at longer intervals after memory reactivation also requires mTORC1-dependent processes that involve S6K1. These findings suggest a potential mechanism for how mTORC1-dependent translation is fine tuned to alter memory persistence.
\end{abstract}

Key words: consolidation; fear conditioning; long-term memory; mTORC1; reconsolidation; translation

\section{Introduction}

New protein synthesis is a fundamental requirement for synaptic plasticity and long-term memory (LTM) formation. The proteins that are synthesized during memory formation are thought to be involved with the stabilization and strengthening of synaptic modifications that allow memories to persist. Moreover, both new learning (consolidation) and memory retrieval (reconsolidation) are disrupted by general protein synthesis inhibitors in several behavioral paradigms (Flexner et al., 1965; Nader et al., 2000).

Central to the regulation of translation is the mammalian target of rapamycin complex 1 (mTORC1) signaling pathway. Activation of mTORC1 triggers the initiation of cap-dependent translation via phosphorylation of eukaryotic translation initiation factor 4E (eIF4E)-binding proteins (4E-BPs) and p70 S6

Received March 4, 2014; revised May 20, 2014; accepted May 22, 2014.

Author contributions: T.N.H., E.S., and E.K. designed research; T.N.H. and E.S. performed research; T.N.H., E.S., and E.K. analyzed data; T.N.H., E.S., and E.K. wrote the paper.

This research was supported by National Institutes of Health Grants R01 NS034007 and NS047384.

The authors declare no competing financial interests.

Correspondence should be addressed to Dr. Eric Klann, Center for Neural Science, New York University, 4 Washington Place, Room 809, New York, NY 10003. E-mail: eklann@ens.nyu.edu.

DOI:10.1523/JNEUROSCI.0878-14.2014

Copyright $\odot 2014$ the authors $\quad 0270-6474 / 14 / 349034-06 \$ 15.00 / 0$ kinase polypeptide 1 (S6K1) (Holz et al., 2005; Richter and Klann, 2009). mTORC1-dependent phosphorylation of 4E-BPs results in the release of eIF4E and its subsequent binding to eIF4G (Gingras et al., 2001). This molecular signaling permits the formation of the eIF4F initiation complex and subsequently cap-dependent protein synthesis. mTORC1 also affects translation by phosphorylating S6K1, which phosphorylates downstream targets such as ribosomal protein S6 and eIF4B (Raught et al., 2004).

Rapamycin, an inhibitor of mTORC1, has been reported to block the consolidation and reconsolidation of both contextual and cued fear memory (Blundell et al., 2008; Mac Callum et al., 2013). However, pharmacological inhibition of eIF4E-eIF4G interactions, which is mTORC1 dependent, blocks the consolidation of cued fear memory but not reconsolidation (Hoeffer et al., 2011). Thus, it is possible that the requirement of mTORC1 downstream effectors may differ during particular memory processes. Indeed, it was shown that S6K1 knock-out mice do not exhibit any impairments in the consolidation of cued fear memory (Antion et al., 2008). These observations are consistent with a differential role of mTORC1 downstream effectors in various forms of synaptic plasticity and memory (Santini et al., 2014).

Identifying molecular distinctions between consolidation and reconsolidation may provide valuable information on the mechanisms underlying memory persistence. Reactivated memories 
remain labile transiently, during which time the memory can be modified using various behavioral manipulations (Monfils et al., 2009; Schiller et al., 2010). Moreover, studies have shown that reconsolidation can lead to additional alterations in memory strength at longer time points after memory retrieval (Lee, 2008; Pan et al., 2012; Da Silva et al., 2013).

Although the role of mTORC1 in reconsolidation has been established, blocking the formation of the eIF4F initiation complex alone did not block reconsolidation (Hoeffer et al., 2011). Therefore, we used S6K1 knock-out mice and a novel pharmacological inhibitor of S6K1 in vivo to study the role of S6K1, and in conjunction with eIF4E-eIF4G interactions, in reconsolidation. Our findings demonstrate that formation of the eIF4F translation initiation complex and activation of S6K1 are concomitant requirements for the reconsolidation of cued fear memory and that these mTORC1 downstream effectors play a differential role in memory maintenance after the memory retrieval. These findings enhance our knowledge of the role of MTORC1 and its downstream effectors, particularly S6K1, in reconsolidation and suggest that S6K1 plays an important role in maintaining memory persistence.

\section{Materials and Methods}

All procedures involving mice were approved by the New York University Animal Care and Use Committee and followed the National Institutes of Health Guidelines for the use of animals in research.

Housing. Mice were housed on a $12 \mathrm{~h}$ light/dark cycle (lights on at 7:00 $\mathrm{AM})$ and were provided food and water ad libitum.

Mice. Experiments were performed in adult male (3 months) C57BL/6 mice (The Jackson Laboratory) or adult (3-5 months) S6K1 knock-out mice and their wild-type littermates as noted. S6K1 knock-out mice were generated as described previously (Shima et al., 1998). S6K1 knock-out mice were originally generated on a 129/SveJ $\times$ C57BL/6 mixed background and backcrossed at least twice with C57BL/6 mice. All experiments were performed with the examiners blind to drug treatment and genotype.

Surgery. Cannulae were unilaterally implanted in the right lateral ventricle as described previously (Santini et al., 2013). Mice were anesthetized with ketamine $(100 \mathrm{mg} / \mathrm{kg})$ and xylazine $(10 \mathrm{mg} / \mathrm{kg})$ and mounted on a stereotaxic apparatus. Cannulae (26 gauge; Plastics One) were implanted at the following coordinates: $20.22 \mathrm{~mm}$ anteroposterior, $11 \mathrm{~mm}$ mediolateral, and $22.4 \mathrm{~mm}$ dorsoventral (Santini et al., 2013). Mice were given at least 1 week after surgery to recover.

Drug preparation. Rapamycin (LC Laboratories) was dissolved in a vehicle solution of $1 \%$ dimethylsulfoxide (DMSO), $5 \%$ Tween 80 , and saline and injected at a dose of $3 \mathrm{mg} / \mathrm{kg}$. PF-4708671 [2-((4-(5ethylpyrimidin-4-yl)piperazin-1-yl)methyl)-5-(trifluoromethyl)- $1 \mathrm{H}$ benzo[d]imidazole; Pfizer] was dissolved in a vehicle solution of $17 \%$ DMSO, $10 \%$ Tween 80 , and saline. Both drugs were injected intraperitoneally to a volume of $5 \mathrm{ml} / \mathrm{kg}$ relative to body weight. $4 \mathrm{EGI}-1$ was prepared as described previously (Hoeffer et al., 2011; Santini et al., 2013). 4EGI-1 (Calbiochem) was dissolved in 100\% DMSO and diluted in vehicle [0.5\% (2hydroxypropyl)-b-cyclodextrin and $1 \%$ DMSO in artificial CSF] to a final concentration of $100 \mu \mathrm{M}$. 4EGI-1 $(1 \mu \mathrm{l})$ was infused intracerebroventricularly at a rate of $0.5 \mu \mathrm{l} / \mathrm{min}$; injectors remained in the guide cannula for $2 \mathrm{~min}$ after the infusion. Control mice received equivalent volumes of vehicle solution.

Biochemistry. The mice were killed $1 \mathrm{~h}$ after treatment with either vehicle or various doses of PF-4708671 (25, 50, and $100 \mathrm{mg} / \mathrm{kg})$. The amygdala was dissected, homogenized, and analyzed using standard Western blotting procedures as described previously (Santini et al., 2013). The following antibodies were used: phospho-Ser240/244-S6 ribosomal protein, phospho-ERK1/2, S6 ribosomal protein, and ERK1/2 (Cell Signaling Technology). Detection and quantification were performed using the Kodak 4000MM imager detection system. The levels of each phosphoprotein were normalized for the amount of the corresponding total protein detected in the sample.
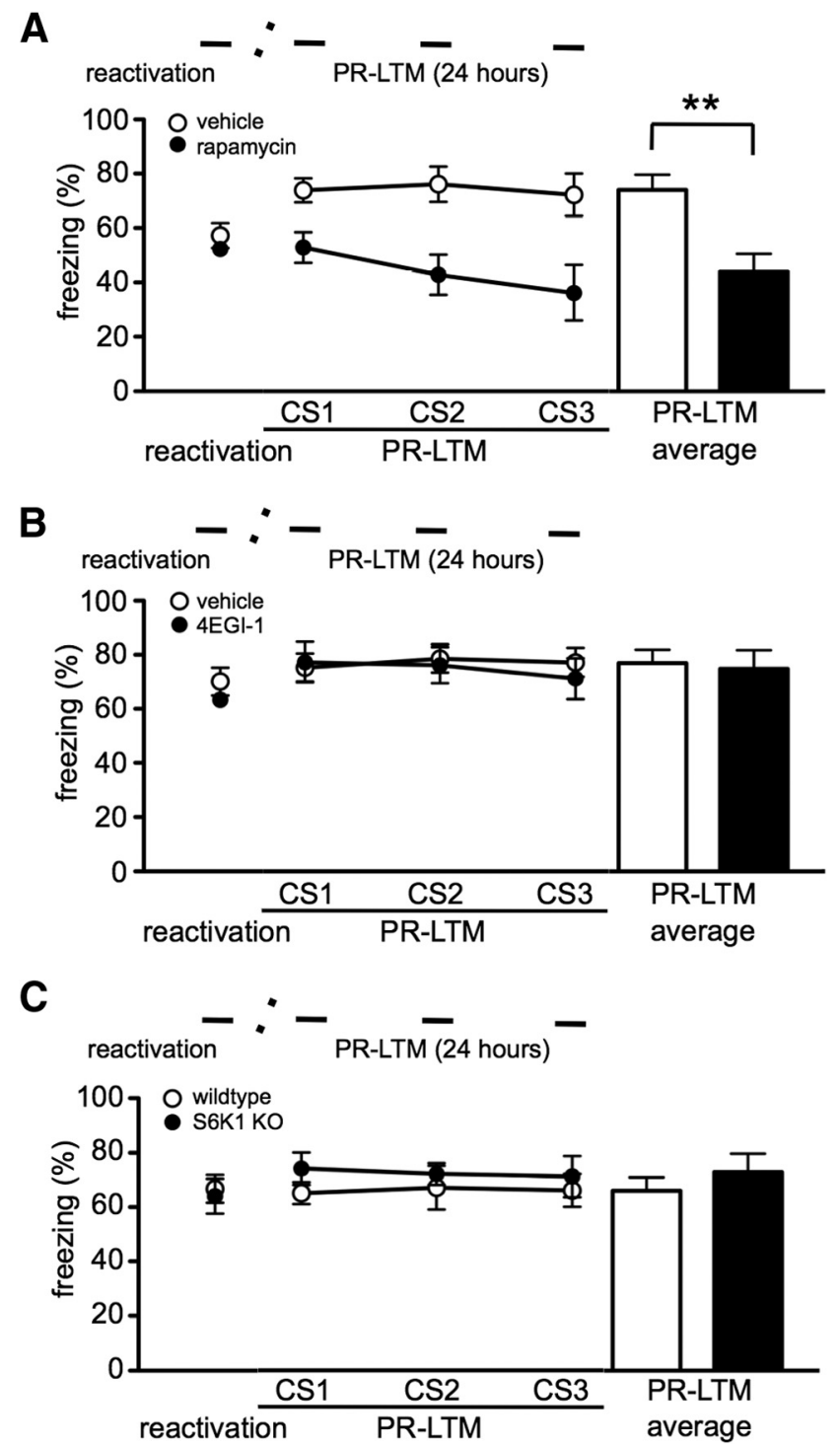

Figure 1. mTORC1 is required for reconsolidation of cued fear memory. Reconsolidation of cued fear memory was tested in mice treated with either vehicle or inhibitors of mTORC 1 and its effectors. $A$, Rapamycin-treated mice ( $n=6$ per treatment) exhibited a significant decrease in freezing behavior during PR-LTM $\left({ }^{* *} p=0.007\right)$. 4EGI-1-treated mice $(\boldsymbol{B}, n=7$ per treatment) and S6K1 knock-out (KO) mice ( $\boldsymbol{C} ; n=6$ per genotype) did not exhibit an impairment in the PR-LTM. The timeline of the experiments is depicted above each figure. Horizontal lines represent the tone (CS) presented during reactivation (1 presentation) or PR-LTMs (3 presentations). Transverse dashed lines symbolize the interval between the reactivation and the PR-LTM test. Data are represented as mean \pm SEM in all graphs.

Fear conditioning. Mice were habituated, trained, and tested in yoked, sound-insulated chambers (GraphicState 2.0; Colbourn Instruments). Mice received $3 \mathrm{~d}$ of habituation to the training context, consisting of a white house light and metal conducting grid floor. On the training day, mice were acclimated to the training chamber for $240 \mathrm{~s}$, followed by two conditioned stimuli (CSs; $30 \mathrm{~s}, 80 \mathrm{~dB}$ tone) presentations, which were coterminated with an unconditioned stimulus ( $0.5 \mathrm{~mA}$ footshock). All mice received memory reactivation $24 \mathrm{~h}$ after training using a single CS presentation, in a novel context, which consisted of a red house light, a white Plexiglas platform, and mouse bedding mixed with vanilla odor. Immediately after memory reactivation, mice were infused and/or injected with the appropriate inhibitor, vehicle, or a combination of both. For the experiments using rapamycin, there was a $3 \mathrm{~d}$ interval before reactivation during which mice received a single injection each day of either rapamycin $(3 \mathrm{mg} / \mathrm{kg})$ or vehicle. This regimen was chosen because 
chronic injections of rapamycin $(5 \mathrm{mg} / \mathrm{kg}$ ) have been found to significantly reduce the activity of mTORC1 downstream effectors in the brain, without affecting other memory-related signaling pathways, such as cAMP and ERK (Ehninger et al., 2008; Santini et al., 2009). Post-reactivation LTM (PR-LTM) was assessed $24 \mathrm{~h}$ after reactivation using three CS presentations in the reactivation context. For the experiments using the S6K1 knock-out mice, the mice received the same timeline of habituation, training, reactivation, and PRLTM test described above but did not receive any injections. For the pharmacology experiments, all mice were retested $10 \mathrm{~d}$ after reactivation with an additional three CS presentations. To confirm that the drug effects were specific to memory retrieval, the inhibitors and vehicle controls were also administered $24 \mathrm{~h}$ after training in the absence of reactivation and then tested for LTM at $24 \mathrm{~h}$ and $10 \mathrm{~d}$. Freezing behavior is represented as a percentage of total tone presentation time.

Statistical analysis. Group data are presented as mean \pm SEM. A one-way ANOVA, followed by Dunnett's post hoc test was used for the Western blot experiments. PR-LTM average and locomotor activity were analyzed with a Student's $t$ test. Ten day PR-LTM and $24 \mathrm{~h}$ PRLTM were compared using a two-way repeated-measures ANOVA. Significant interactions or main effects were followed by Bonferroni's post hoc tests.

\section{Results}

Previous reports have shown that rapamycin blocks the reconsolidation of contextual and cued fear memory (Blundell et al., 2008; Mac Callum et al., 2013). Because a dose of $1 \mathrm{mg} / \mathrm{kg}$ was found previously to be sufficient to block fear memory (Blundell et al., 2008), we used rapamycin at a dose of $3 \mathrm{mg} / \mathrm{kg}$ to study the impact of mTORC1 inhibition on cued fear memory reconsolidation. Mice received a single CS presentation for memory reactivation and were injected immediately afterward with either rapamycin (3 $\mathrm{mg} / \mathrm{kg}$ ) or vehicle. The rapamycin-treated mice showed a significant reduction in PR-LTM compared with vehicle-treated groups $\left(t_{(5)}\right.$ $=4.364, p=0.007$; Fig. $1 A$ ). These data are consistent with previous reports that inhibition of mTORC1 impairs the reconsolidation of cued fear memory (Mac Callum et al., 2013).

We proceeded to determine the role of mTORC1 downstream effectors on cued fear memory reconsolidation. To determine whether eIF4E-eIF4G interactions are required for reconsolidation in mice, we infused 4EGI-1 intracerebroventricularly immediately after reactivation. Consistent with our previous report in rats, 4EGI-1 did not impair cued fear memory reconsolidation $(t$ test, $p=0.875$; Fig. $1 B$; Hoeffer et al., 2011). Because rapamycin blocks cued fear memory reconsolidation (Fig. $1 A$ ) but inhibition of eIF4E-eIF4G interactions does not, we hypothesized that S6K1 might play a more critical role in this memory process. To test this notion, we used constitutive S6K1 knock-out mice and examined reconsolidation. Interestingly, S6K1 knock-out mice did not exhibit an impairment in PR-LTM ( $t$ test, $p=0.863$; Fig. $1 C)$. These results suggest that $\mathrm{S} 6 \mathrm{~K} 1$ alone is not required for reconsolidation.

To confirm the results obtained with the S6K1 knock-out mice, we proceeded to use an S6K1 inhibitor to study reconsoli- dation. Although PF-4708671 has been demonstrated to be a specific inhibitor of S6K1, most of the studies have been conducted in cell culture lines, and it has not been used to study the role of S6K1 in cognitive function to date (Bilanges and Vanhaesebroeck, 2010; Pearce et al., 2010). Therefore, we performed a dose-response curve using PF-4708671 to determine the appropriate concentration that would reduce S6 ribosomal protein phosphorylation in the brain. We found a significant reduction in S6 phosphorylation (Ser240/244) $1 \mathrm{~h}$ after injection of PF4708671 at doses of 50 and $100 \mathrm{mg} / \mathrm{kg}$ (one-way ANOVA, $F_{(3,12)}=$ $11.55, p=0.0007$, followed by Dunnett's post hoc test; Fig. $2 A$ ). We also found that PF-4708671 did not affect ERK phosphorylation (one-way ANOVA, n.s.; Fig. 2B), another protein kinase required for memory consolidation, indicating that $\mathrm{PF}-4708671$ was selective for S6K1 (Schafe et al., 2000). Last, PF-4708671 at a dose of $50 \mathrm{mg} / \mathrm{kg}$ did not affect locomotor activity ( $t$ test, $p=$ 0.518; Fig. 2C). Therefore, we injected mice immediately after reactivation with either vehicle or $50 \mathrm{mg} / \mathrm{kg} \mathrm{PF}-4708671$. We found that pharmacological inhibition of S6K1 did not impair reconsolidation of cued fear memory ( $t$ test, $p=0.935$; Fig. $2 D$ ). These results are consistent with our findings with the S6K1 knock-out mice and indicate that $\mathrm{S} 6 \mathrm{~K} 1$ alone is not required for the reconsolidation of cued fear memory.

Because inhibition of either eIF4E-eIF4G interactions or S6K1 activity alone are not sufficient to block reconsolidation, we postulated that cued fear memory reconsolidation requires concomitant formation of the eIF4F complex and S6K1 activity. To test this idea, we infused 4EGI-1 and injected PF-4708671 imme- 
A

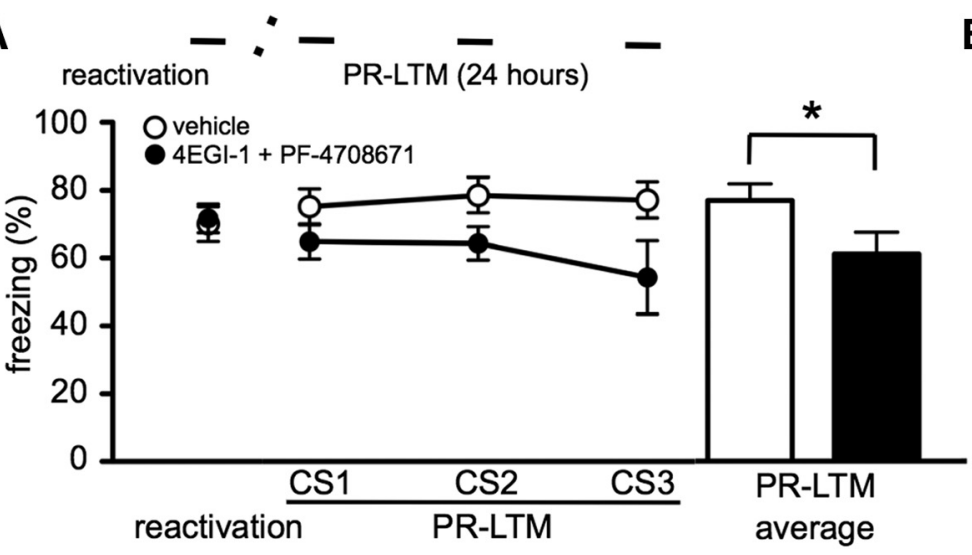

B

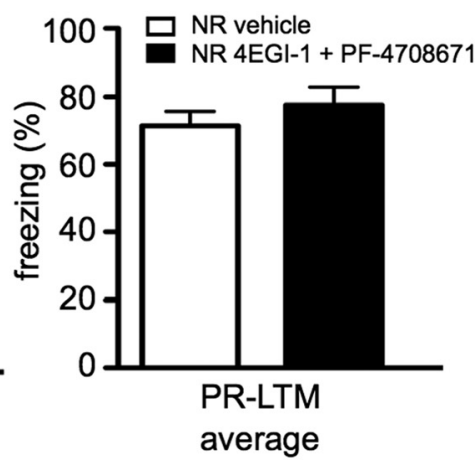

Figure 3. Concomitant association of elF4E to elF4G and S6K activity is required for reconsolidation of cued fear memory. Reconsolidation of cued fear memory was tested in mice treated with either vehicle or a combination of 4EGI-1 (100 $\mu \mathrm{m}$ ) and PF-4708671 (50 mg/kg; $n=7$ per treatment). $A$, Mice treated with $4 \mathrm{EGI}-1$ and PF-4708671 exhibited a significant decrease in freezing behavior during PR-LTM ( ${ }^{*} p=0.041$ ). $B$, Mice treated with 4EGI-1 and PF-4708671 did not exhibit impaired LTM when the drugs were administered with no reactivation (NR; $n=6$ per treatment). Data are represented as mean $\pm S E M$ in all graphs.
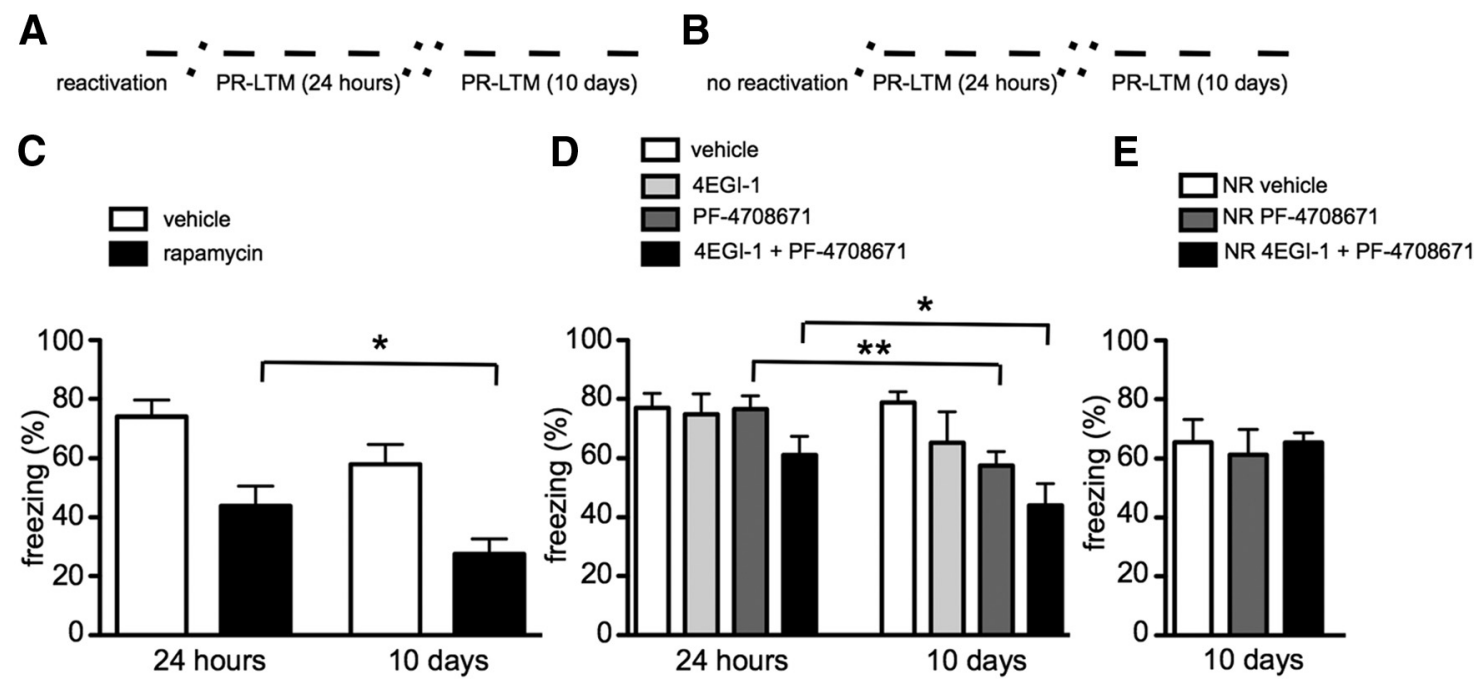

Figure 4. $\mathrm{mTORC} 1$ and S6K1 are required for the persistence of cued fear memory. $\boldsymbol{A}, \boldsymbol{B}$, Timeline of the experiments summarized. Transverse dashed lines symbolize the $24 \mathrm{~h}$ and $10 \mathrm{~d}$ interval between the reactivation and the two PR-LTM tests. $C$, Mice treated with rapamycin ( $n=6$ per treatment) after reactivation displayed a reduction in freezing behavior in the $24 \mathrm{~h}$ and $10 \mathrm{~d}$ PR-LTM tests ( $\left.{ }^{*} p<0.05\right)$. D, Mice were treated with vehicle, 4EGI-1 (100 $\left.\mu \mathrm{m}\right)$, PF-4708671 (50 mg/kg), or a combination of the two after reactivation. Mice that received either PF-4708671 alone or a combination of 4EGI-1 and PF-4708671 exhibited a decrease in freezing behavior during the $10 \mathrm{~d}$ PR-LTM test $\left({ }^{*} p<0.05 ;{ }^{* *} p<0.01\right)$. E, Mice treated with the combination of either $4 \mathrm{EGI}-1$ and PF-4708671 or PF-4708671 alone did not exhibit impaired LTM at $10 \mathrm{~d}$ when the drugs were administered with no reactivation (NR). Data are represented as mean \pm SEM in all graphs.

diately after reactivation. Indeed, mice receiving 4EGI-1 and PF4708671 demonstrated an impairment in PR-LTM $\left(_{(6)}=2.592\right.$, $p=0.041$; Fig. $3 A$ ). To confirm that the combined effect of 4EGI-1 and PF-4708671 was specific to reconsolidation updating mechanisms, we administered either the combination of drugs or vehicle to mice with no reactivation. The mice treated with 4EGI-1 and PF-4708671 did not show an impairment in LTM when the drugs were administered in the absence of reactivation ( $t$ test, $p=0.373$; Fig. $3 B$ ). These studies are the first to use 4EGI-1 and PF-4708671 in combination and suggest that both eIF4F complex formation and activation of $\mathrm{S} 6 \mathrm{~K} 1$ are required for the reconsolidation of cued fear memory.

As mentioned previously, reconsolidation is an excellent tool to study the fine molecular details of memory persistence. To determine whether inhibition of mTORC1, eIF4E-eIF4G interactions, and/or S6K1 results in any alteration in the post-retrieval fragility of a memory with the passage of time, we retested the mice $10 \mathrm{~d}$ after reactivation (Fig. 4A). Mice treated with rapamy- cin exhibited an additional decrement in memory strength $10 \mathrm{~d}$ after memory reactivation compared with $24 \mathrm{~h}$ after reactivation (two-way repeated-measures ANOVA, significant effect of time $\times$ treatment interaction, $F_{(1,10)}=4.990, p=0.0495$; Fig. $4 C)$. For the mice treated with 4EGI-1, PF-4708671, or 4EGI-1 plus PF-4708671, a two-way repeated-measures ANOVA revealed a significant time $\times$ treatment interaction $\left(F_{(3,24)}=2.963\right.$, $p=0.0483$; Fig. $4 D$ ). Consistent with the effect of rapamycin on the PR-LTM at $24 \mathrm{~h}$ and $10 \mathrm{~d}$, mice that received infusions of 4EGI-1 and an injection of PF-4708671 also exhibited an additional decrease in memory retention at $10 \mathrm{~d}$ compared with $24 \mathrm{~h}$ (Bonferroni's post hoc test, $p<0.05$; Fig. $4 D$ ). Mice treated with 4 EGI-1 alone did not exhibit a significant difference in memory strength $10 \mathrm{~d}$ after reactivation compared with $24 \mathrm{~h}$ after reactivation. Interestingly, mice treated with PF-4708671 alone exhibited a decrease in memory strength $10 \mathrm{~d}$ after reactivation (Bonferroni's post hoc test, $p<0.01$; Fig. 4D). To confirm that the roles of PF-4708671 and the combination of 4EGI-1 and PF- 
4708671 on memory strength at $10 \mathrm{~d}$ after reactivation is specific to reconsolidation updating mechanisms, we injected mice $24 \mathrm{~h}$ after training in the absence of reactivation (Fig. 4B). Indeed, neither PF-4708671 nor the combination of 4EGI-1 and PF$4708671 \mathrm{had}$ an effect on memory strength at $10 \mathrm{~d}$ when administered in the absence of reactivation (one-way ANOVA, n.s.; Fig. $4 E$ ). These results indicate a role for mTORC1-dependent translation in maintaining memory at longer time points after reactivation and also indicate that $\mathrm{S} 6 \mathrm{~K} 1$ is required for this process.

\section{Discussion}

Our findings demonstrate that fear memory reconsolidation requires concomitant formation of eIF4F and activation of S6K1. The novel use of 4EGI-1 and PF-4708671 in concert has allowed us to demonstrate that both of these mTORC1 downstream effectors are required for fear memory reconsolidation. Our results also indicate that inhibition of both mTORC1 effectors immediately after reactivation disrupts memory that is measured $24 \mathrm{~h}$ after reactivation and is further destabilized $10 \mathrm{~d}$ after reactivation. Interestingly, there is a differential requirement of the effectors of mTORC1 in maintaining memory at longer time points after reactivation, because inhibition of $\mathrm{S} 6 \mathrm{~K} 1$ alone resulted in a decrease in memory retention measured $10 \mathrm{~d}$, but not $24 \mathrm{~h}$, after reactivation. In contrast, inhibition of eIF4E-eIF4G interactions did not result in a decrement in memory at either time point. These results provide additional evidence that mTORC1 effectors are differentially required for various learning and memory processes (Hoeffer et al., 2011; Santini et al., 2014).

A current theory about the mechanism of memory reconsolidation is that it involves the restructuring of synapses (Kim et al., 2010). In support of this theory, memory retrieval was found to restabilize training-induced synaptic potentiation in the lateral nucleus of the amygdala through a postsynaptic mechanism that was blocked by rapamycin treatment (Li et al., 2013). It has been hypothesized that the restructuring of synapses during reconsolidation is mediated by both protein synthesis and protein degradation mechanisms (Lee et al., 2008,2012; Kaang and Choi, 2012). For example, the amnesic effects of inhibiting L-type voltage-gated calcium channels and protein synthesis during reconsolidation were abolished by concomitantly inhibiting proteasome activity (Da Silva et al., 2013). Our results are consistent with the role of de novo protein synthesis in memory reconsolidation. Moreover, the decrease in memory strength that is observed by post-retrieval inhibition of S6K1 at $10 \mathrm{~d}$ after reactivation, but not at $24 \mathrm{~h}$, suggests that one mTORC1 effector, $\mathrm{S} 6 \mathrm{~K} 1$, is required for the fine tuning of de novo protein synthesis necessary for memory persistence. Notably, in addition to its role in fear memory reconsolidation, $\mathrm{mTORC} 1$ has been demonstrated to be necessary for the reconsolidation of drug-seeking behavior, inhibitory avoidance and object recognition (Jobim et al., 2012a,b; Lin et al., 2014). Thus, the study of mTORC1-dependent processes on memory modulation is of strong therapeutic value given its ubiquity in several reconsolidation paradigms.

It should be noted that there is evidence for reconsolidation as a memory-strengthening mechanism (Lee, 2008; Inda et al., 2011). Although we did not observe a difference in memory retention $24 \mathrm{~h}$ after reactivation compared with $10 \mathrm{~d}$ after reactivation in vehicle-treated groups, previous studies reporting a strengthening of memory after retrieval were performed in rats and involved a type of instrumental learning rather than fear conditioning. Moreover, in other studies of cued fear conditioning, differences in memory strength at multiple time points up to
16 weeks after reactivation were not observed (Pitman et al., 2011; Pan et al., 2012).

The formation of the eIF4F translation initiation complex and the activation of S6K1 are two ways in which cap-dependent translation can be regulated. Moreover, accumulating evidence suggests that these mTORC1 effectors differentially regulate the translation of specific subsets of mRNAs (Hsieh et al., 2012; Thoreen et al., 2012; Bowling et al., 2014). In fact, of the mRNAs that are mTORC1 dependent, a significant portion of them are also sensitive to eIF4E inhibition but not S6K1 inhibition (Thoreen et al., 2012). Conversely, there is also support for alterations in protein synthesis after S6K1 inhibition that may be attributable to changes in translation elongation (Bhattacharya et al., 2012; Bowling et al., 2014). Our finding that the combined efforts of eIF4F formation and S6K1 activity are necessary for reconsolidation is in support of the emerging evidence that the two mTORC1 effectors are responsible for distinct mechanisms of translation regulation. However, it remains to be determined whether the mTORC1 effectors differentially regulated the translation of specific subsets of mRNAs in the brain.

The differential roles of the mTORC1 effectors have been observed behaviorally in the reconsolidation of cued fear memory. As discussed previously, inhibition of mTORC1 blocks the consolidation and reconsolidation of cued fear memory, but inhibition of eIF4E-eIF4G interactions blocks only consolidation (Hoeffer et al., 2011; Mac Callum et al., 2013). In addition, our results indicate that $\mathrm{mTORC1-dependent} \mathrm{translation} \mathrm{is} \mathrm{required}$ to maintain the PR-LTM at longer time points after reactivation (Fig. 4C). Specifically, the combined inhibition of eIF4F formation and S6K1 demonstrates that mTORC1-dependent translation is involved with the maintenance of memory $10 \mathrm{~d}$ after reactivation (Fig. 4D). This requirement of $\mathrm{mTORC1}$ appears to be attributable to activation of S6K1 because inhibiting S6K1, but not eIF4E-eIF4G interactions, impaired PR-LTM $10 \mathrm{~d}$ after reactivation (Fig. 4D). S6K1 can regulate translation initiation via phosphorylation of eIF4B, which stimulates the helicase activity of eIF4A (Raught et al., 2004). Thus, it is possible that eIF4Adependent translation is required for PR-LTM at longer time points after reactivation. Alternatively, because S6K1 affects both translation initiation and elongation whereas eIF4E-eIF4G interactions controls translation initiation, the differential requirement for S6K1 in maintaining PR-LTM $10 \mathrm{~d}$ after reactivation could be attributable to S6K1-dependent translation elongation.

Overall, our results demonstrate that mTORC1-dependent translation in the reconsolidation of fear memory requires the combined effect of eIF4F formation and S6K1 activation. Moreover, our studies establish that $\mathrm{S} 6 \mathrm{~K} 1$, but not eIF4F, is required for maintaining memory $10 \mathrm{~d}$ after reactivation, indicating a differential requirement for $\mathrm{mTORC} 1$ downstream effectors in the persistence of memory reconsolidation.

\section{References}

Antion MD, Merhav M, Hoeffer CA, Reis G, Kozma SC, Thomas G, Schuman EM, Rosenblum K, Klann E (2008) Removal of S6K1 and S6K2 leads to divergent alterations in learning, memory, and synaptic plasticity. Learn Mem 15:29-38. CrossRef Medline

Bhattacharya A, Kaphzan H, Alvarez-Dieppa AC, Murphy JP, Pierre P, Klann E (2012) Genetic removal of p70 S6 kinase 1 corrects molecular, synaptic, and behavioral phenotypes in fragile X syndrome mice. Neuron 76 : 325-337. CrossRef Medline

Bilanges B, Vanhaesebroeck B (2010) A new tool to dissect the function of p70 S6 kinase. Biochem J 431:e1-e3. CrossRef Medline

Blundell J, Kouser M, Powell CM (2008) Systemic inhibition of mammalian target of rapamycin inhibits fear memory reconsolidation. Neurobiol Learn Mem 90:28-35. CrossRef Medline 
Bowling H, Zhang G, Bhattacharya A, Pérez-Cuesta LM, Deinhardt K, Hoeffer CA, Neubert TA, Gan WB, Klann E, Chao MV (2014) Antipsychotics activate mTORC1-dependent translation to enhance neuronal morphological complexity. Sci Signal 7:ra4. CrossRef Medline

Da Silva WC, Cardoso G, Bonini JS, Benetti F, Izquierdo I (2013) Memory reconsolidation and its maintenance depend on L-voltage-dependent calcium channels and CaMKII functions regulating protein turnover in the hippocampus. Proc Natl Acad Sci U S A 110:6566-6570. CrossRef Medline

Ehninger D, Han S, Shilyansky C, Zhou Y, Li W, Kwiatkowski DJ, Ramesh V, Silva AJ (2008) Reversal of learning deficits in a Tsc2 +/ - mouse model of tuberous sclerosis. Nat Med 14:843-848. CrossRef Medline

Flexner LB, Flexner JB, Stellar E (1965) Memory and cerebral protein synthesis in mice as affected by graded amounts of puromycin. Exp Neurol 13:264-272. CrossRef Medline

Gingras AC, Raught B, Sonenberg N (2001) Regulation of translation initiation by FRAP/mTOR. Genes Dev 15:807-826. CrossRef Medline

Hoeffer CA, Cowansage KK, Arnold EC, Banko JL, Moerke NJ, Rodriguez R, Schmidt EK, Klosi E, Chorev M, Lloyd RE, Pierre P, Wagner G, LeDoux JE, Klann E (2011) Inhibition of the interactions between eukaryotic initiation factors $4 \mathrm{E}$ and $4 \mathrm{G}$ impairs long-term associative memory consolidation but not reconsolidation. Proc Natl Acad Sci U S A 108:33833388. CrossRef Medline

Holz MK, Ballif BA, Gygi SP, Blenis J (2005) mTOR and S6K1 mediate assembly of the translation preinitiation complex through dynamic protein interchange and ordered phosphorylation events. Cell 123:569-580. CrossRef Medline

Hsieh AC, Liu Y, Edlind MP, Ingolia NT, Janes MR, Sher A, Shi EY, Stumpf CR, Christensen C, Bonham MJ, Wang S, Ren P, Martin M, Jessen K, Feldman ME, Weissman JS, Shokat KM, Rommel C, Ruggero D (2012) The translational landscape of mTOR signalling steers cancer initiation and metastasis. Nature 485:55-61. CrossRef Medline

Inda MC, Muravieva EV, Alberini CM (2011) Memory retrieval and the passage of time: from reconsolidation and strengthening to extinction. J Neurosci 31:1635-1643. CrossRef Medline

Jobim PFC, Pedroso TR, Christoff RR, Werenicz A, Maurmann N, Reolon GK, Roesler R (2012a) Inhibition of mTOR by rapamycin in the amygdala or hippocampus impairs formation and reconsolidation of inhibitory avoidance memory. Neurobiol Learn Mem 97:105-112. CrossRef Medline

Jobim PFC, Pedroso TR, Werenicz A, Christoff RR, Maurmann N, Reolon GK, Schröder N, Roesler R (2012b) Impairment of object recognition memory by rapamycin inhibition of mTOR in the amygdala or hippocampus around the time of learning or reactivation. Behav Brain Res 228:151-158. CrossRef Medline

Kaang BK, Choi JH (2012) Synaptic protein degradation in memory reorganization. Adv Exp Med Biol 970:221-240. CrossRef Medline

Kim J, Song B, Hong I, Kim J, Lee J, Park S, Eom JY, Lee CJ, Lee S, Choi S (2010) Reactivation of fear memory renders consolidated amygdala synapses labile. J Neurosci 30:9631-9640. CrossRef Medline

Lee JLC (2008) Memory reconsolidation mediates the strengthening of memories by additional learning. Nat Neurosci 11:1264-1266. CrossRef Medline

Lee SH, Choi JH, Lee N, Lee HR, Kim JI, Yu NK, Choi SL, Lee SH, Kim H, Kaang BK (2008) Synaptic protein degradation underlies destabilization of retrieved fear memory. Science 319:1253-1256. CrossRef Medline

Lee SH, Kwak C, Shim J, Kim JE, Choi SL, Kim HF, Jang DJ, Lee JA, Lee K, Lee CH, Lee YD, Miniaci MC, Bailey CH, Kandel ER, Kaang BK (2012) A cellular model of memory reconsolidation involves reactivation-induced destabilization and restabilization at the sensorimotor synapse in Aplysia. Proc Natl Acad Sci U S A 109:14200-14205. CrossRef Medline
Li Y, Meloni EG, Carlezon WA Jr, Milad MR, Pitman RK, Nader K, Bolshakov VY (2013) Learning and reconsolidation implicate different synaptic mechanisms. Proc Natl Acad Sci U S A 110:4798-4803. CrossRef Medline

Lin J, Liu L, Wen Q, Zheng C, Gao Y, Peng S, Tan Y, Li Y (2014) Rapamycin prevents drug seeking via disrupting reconsolidation of reward memory in rats. Int J Neuropsychopharmacol 17:127-136. CrossRef Medline

Mac Callum PE, Hebert M, Adamec RE, Blundell J (2013) Systemic inhibition of mTOR kinase via rapamycin disrupts consolidation and reconsolidation of auditory fear memory. Neurobiol Learn Mem. Advance online publication. Retrieved June 6, 2014. doi:10.1016/j.nlm.2013.08.014. CrossRef

Monfils MH, Cowansage KK, Klann E, LeDoux JE (2009) Extinctionreconsolidation boundaries: key to persistent attenuation of fear memories. Science 324:951-955. CrossRef Medline

Nader K, Schafe GE, Le Doux JE (2000) Fear memories require protein synthesis in the amygdala for reconsolidation after retrieval. Nature 406: 722-726. CrossRef Medline

Pan YW, Storm DR, Xia Z (2012) The maintenance of established remote contextual fear memory requires ERK5 MAP kinase and ongoing adult neurogenesis in the hippocampus. PLoS One 7:e50455. CrossRef Medline

Pearce LR, Alton GR, Richter DT, Kath JC, Lingardo L, Chapman J, Hwang C, Alessi DR (2010) Characterization of PF-4708671, a novel and highly specific inhibitor of p70 ribosomal S6 kinase (S6K1). Biochem J 431:245255. CrossRef Medline

Pitman RK, Milad MR, Igoe SA, Vangel MG, Orr SP, Tsareva A, Gamache K, Nader K (2011) Systemic mifepristone blocks reconsolidation of cueconditioned fear; propranolol prevents this effect. Behav Neurosci 125: 632-638. CrossRef Medline

Raught B, Peiretti F, Gingras AC, Livingstone M, Shahbazian D, Mayeur GL, Polakiewicz RD, Sonenberg N, Hershey JWB (2004) Phosphorylation of eucaryotic translation initiation factor 4B Ser422 is modulated by S6 kinases. EMBO J 23:1761-1769. CrossRef Medline

Richter JD, Klann E (2009) Making synaptic plasticity and memory last: mechanisms of translational regulation. Genes Dev 23:1-11. CrossRef Medline

Santini E, Heiman M, Greengard P, Valjent E, Fisone G (2009) Inhibition of mTOR signaling in Parkinson's disease prevents L-DOPA-induced dyskinesia. Sci Signal 2:ra36. CrossRef Medline

Santini E, Huynh TN, MacAskill AF, Carter AG, Pierre P, Ruggero D, Kaphzan H, Klann E (2013) Exaggerated translation causes synaptic and behavioural aberrations associated with autism. Nature 493:411-415. CrossRef Medline

Santini E, Huynh TN, Klann E (2014) Mechanisms of translation control underlying long-lasting synaptic plasticity and the consolidation of longterm memory. Prog Mol Biol Transl Sci 122:131-167. CrossRef Medline

Schafe GE, Atkins CM, Swank MW, Bauer EP, Sweatt JD, LeDoux JE (2000) Activation of ERK/MAP kinase in the amygdala is required for memory consolidation of pavlovian fear conditioning. J Neurosci 20:8177-8187. Medline

Schiller D, Monfils MH, Raio CM, Johnson DC, Ledoux JE, Phelps EA (2010) Preventing the return of fear in humans using reconsolidation update mechanisms. Nature 463:49-53. CrossRef Medline

Shima H, Pende M, Chen Y, Fumagalli S, Thomas G, Kozma SC (1998) Disruption of the $\mathrm{p} 70(\mathrm{~s} 6 \mathrm{k}) / \mathrm{p} 85(\mathrm{~s} 6 \mathrm{k})$ gene reveals a small mouse phenotype and a new functional S6 kinase. EMBO J 17:6649-6659. CrossRef Medline

Thoreen CC, Chantranupong L, Keys HR, Wang T, Gray NS, Sabatini DM (2012) A unifying model for mTORC1-mediated regulation of mRNA translation. Nature 485:109-113. CrossRef Medline 